\title{
Homoranthus binghiensis (Myrtaceae: Chamaelaucieae), a new species from the North Western Slopes of New South Wales
}

\author{
John T. Hunter ${ }^{1}$ and Lachlan M. Copeland ${ }^{2}$
}

\begin{abstract}
Hunter, John T ${ }^{1}$. and Copeland, Lachlan M. ${ }^{2}\left({ }^{1} 75\right.$ Kendall Rd, Invergowrie, NSW 2350, Australia, ${ }^{2}$ Division of Botany, University of New England, Armidale, NSW 2351, Australia) 2001. Homoranthus binghiensis (Myrtaceae), a new species from the North Western Slopes of New South Wales Telopea 9(2): 431-433. Homoranthus binghiensis J.T. Hunter, a new species from the Torrington region of the North Western Slopes of New South Wales is described and notes are provided on its distribution and conservation status. The species is distinguished from its putative sister taxa by particularly thick leaves and a combination of ovule and sepal laciniae number.
\end{abstract}

\section{Introduction}

During a vegetation survey of the Torrington State Recreation Area (Clarke et al. 1998) an unusual and very distinctive Homoranthus was discovered. The specimens collected of this entity were shown to represent a geographically restricted unnamed species, which seems not to have been previously collected. This species is described in this paper and notes are given on its distribution, conservation status and putative affinities.

Homoranthus binghiensis J.T. Hunter, sp. nov.

Similis $H$. croftianus, frutex folia 8-22 mm longa, 0.4-0.9 mm lata, 1.3-2.6 incrassatus; flores in ramulis non specialis; pedunculis $0.4-1.2 \mathrm{~mm}$ longis; bracteolis caducis, 4-6.8 $\mathrm{mm}$ longis; hypanthium 4-7 mm longum, 1.4-2.4 mm latums; sepala 3-4.5 mm longa; stylus 5-6.5 mm longus differt.

Type: New South Wales: North Western Slopes: Torrington State Recreation Area, $300 \mathrm{~m}$ SW of junction of Tin Pot Gully and Carpet Snake Creek, 29¹4'44"S, 151 30'18"E, $800 \mathrm{~m}$ altitude, Copeland 2741 E Clarke, 14 Nov 2000 (holo NSW; iso BRI, CANB, MEL, NE).

Shrub to $3 \mathrm{~m}$ tall, erect, fruticous to $2 \mathrm{~m}$ wide. Stems yellow-orange when young turning grey-brown. Leaves opposite, decussate, 8-26 mm long, 1.3-2.6 mm thick and 0.4-0.9 mm wide; incurved to falcate in side view, narrow oblanceolate to oblanceolate, flat in transverse section, pale lime-green to glaucous, apex curved, with a mucro or apiculum, $0.2-0.4 \mathrm{~mm}$ long; petiole $0.7-1.7 \mathrm{~mm}$ long. Flowers solitary in axils but appearing paired in pseudoflorescences, yellow to pale green turning red with age. Peduncles 0.4-1.2 mm long; bracteoles caducous, 4-6.8 mm long, yellowbrown. Hypanthium 5-costate, \pm ruminate between the costae but becoming smooth with age, 4-7 mm long, 1.4-2.4 $\mathrm{mm}$ wide. Sepals 3-4.5 $\mathrm{mm}$ long, $0.4-1.3 \mathrm{~mm}$ wide, apex variously divided into (2-) 3 (-6) laciniae, often with two major divisions and further divisions along primary division, gland dotted at the base. Petals broadly ovate to circular, sometimes erect and clawed, 1.4-2.4 mm long, 1.4-1.8 mm wide, the margin entire. Stamens 10; filaments $0.4-0.7 \mathrm{~mm}$ long; anthers $0.2-0.4 \mathrm{~mm}$ long; staminodes 10 , 
free, 0.3-0.6 mm long. Style 5-6.5 mm long, trichomatous in upper region; ovules 7-8, collateral in two longitudinal rows. Fruit a simple, dry indehiscent nut, $4.4-7 \mathrm{~mm}$ long, 1.5-2.4 mm wide, caducous after seed set, red-brown.

Additional specimens: New South Wales: North Western Slopes: Jonquil Knob, 500 m north of Carpet Snake Trail, Torrington State Recreation Area, south-west of Tenterfield (29 $11^{\prime} 21^{\prime \prime} \mathrm{S}$ $\left.151^{\circ} 32^{\prime} 14 " \mathrm{E}\right)$, in shrubland on shallow soils on granite outcrop, $800 \mathrm{~m}$ altitude, Hunter $\mathcal{E}$ Croft, 20 Nov 1998 (BRI, CANB, MEL, NSW); Jonquil Knob, 500 m north of Carpet Snake Trail, Torrington State Recreation Area, south-west of Tenterfield, Hunter, 15 Jun 1999 (BRI, CANB, MEL, NSW); Torrington SRA, $2.5 \mathrm{~km}$ south of Tin Pot Gully on Carpet Snake Trail, 29 $15^{\prime} \mathrm{S}, 1^{\circ} 1^{\circ} 29^{\prime} \mathrm{E}, 900 \mathrm{~m}$ altitude, Copeland 808 \& Clarke, 17 Nov 1997 (BRI, CANB, MEL, NSW, NE).

Distribution: Homoranthus binghiensis is restricted to the northern and western fall of the Torrington State Recreation Area, which lies within the North Western Slopes of New South Wales south west of Tenterfield. The known distribution of the species is highly scattered and disjunct over 10-15 km.

Flowering: November to January.

Habitat: found in open and exposed situations on and around the margins of granite outcrops between 700-950 m above sea level. The mean annual rainfall of this area is $700-800 \mathrm{~mm}$. The species is found in shrublands and heath on shallow soil depressions on granite outcrops or on shallow soils around their margins. Associated species include Eucalyptus prava, Eucalyptus dealbata and Callitris endlicheri in the overstorey and Calytrix tetragona, Babingtonia odontocalyx, Leptospermum trinervium, Kunzea bracteolata, Leucopogon melaleucoides, and Leptospermum novae-angliae in the shrub layer.

Notes: Homoranthus binghiensis is easily distinguished morphologically from its congeners in New South Wales by its large stature and thick leaves. Affinities are uncertain at this stage but probably lie with $H$. biflorus, $H$. croftianus and $H$. montanus. Homoranthus binghiensis can be also be distinguished from $H$. croftianus and $H$. biflorus by having fewer ovules and from $H$. montanus by having 2-6 sepal laciniae (Table 1). Craven and Jones (1991) considered the former character to be particularly useful in determining relationships within the genus. Clarke and Fulloon (1999) have shown that $H$. binghiensis is an obligate seeder.

Table 1. Diagnostic characters for Homoranthus binghiensis and putative sister taxa.

$\begin{array}{llll} & \text { Sepal laciniae } & \text { Ovule number } & \begin{array}{l}\text { Leaf thickness: } \\ \text { width }\end{array} \\ \text { H. binghiensis } & 2-6 & 7-8 & >4: 1 \\ \text { H. biflorus } & 3-5 & 8-11 & 1: 1 \\ \text { H. croftianus } & 1-3 & 10-11 & 2: 1 \\ \text { H. montanus } & 1 & 6-9 & 1: 1\end{array}$

Conservation status: in the vegetation survey report for Torrington State Recreation Area (Clarke et al. 1998) a ROTAP code (Briggs \& Leigh 1996) of 2K was proposed for the species. However, based on only five currently known populations, the small size of each population, the limited distribution and threats from inappropriate fire regimes, a ROTAP code of $2 \mathrm{VCt}$ is recommended.

Etymology: the area to the west of Torrington that is part of a granite batholith surrounded in the south, west and north by Permian sedimentary rocks has for some time been known as Binghi. Hence, the specific epithet is in reference to the type locality. 


\section{Acknowledgments}

Thanks to Peter Croft, Senior Ranger with the New England Tablelands Region of the New South Wales National Parks and Wildlife Service for assistance in the field. Cathy Nano also provided assistance in the field. Lyn Craven and Peter Wilson are thanked for discussion of Homoranthus taxa.

\section{References}

Briggs, J.D. \& Leigh, J.H. (1996) Rare or Threatened Australian Plants, revised edition. (CSIRO Publishing: Collingwood).

Clarke, P.J., Copeland, L.M., Hunter, J.T., Nano, C.E., Williams, J.B., \& Wills, K.E. (1998) The Vegetation and Plant Species of Torrington State Recreation Area. (University of New England: Armidale).

Clarke, P.J. \& Fulloon, L. (1999) Fire and Rare Plants: Torrington State Recreation Area. Unpublished report to the New South Wales National Parks and Wildlife Service.

Craven, L.A. \& Jones, S.R. (1991) A taxonomic review of Homoranthus and two new species of Darwinia (both Myrtaceae, Chamelaucieae). Australian Systematic Botany 4: 513-533.

Hunter, J.T. (1998) Two new rare species of Homoranthus (Myrtaceae: Chamelaucieae) from the Northern Tablelands of New South Wales. Telopea 8: 35-40.

Manuscript received 17 August 2000

Manuscript accepted 3 May 2001 